\title{
Autoimmun endocrinopathiák kapcsolata a diabetes mellitussal
}

\author{
Bakos Bence dr., Takács István dr.
}

\begin{abstract}
Összefoglalás
Szinte minden endokrin zavar jelentös hatást gyakorol a szénhidrát-anyagcserére, ami valódi diagnosztikus és terápiás kihivást jelent a kezelöorvos számára. Az endokrin szervek alul-, illetve túlmüködésével járó betegségeinek hátterében sokszor autoimmun mechanizmus áll. Bár a gyakorló diabetológus számára ezen kórképek közül legfontosabb az 1-es típusú cukorbetegség, a mindennapi gyakorlat szempontjából azonban a többi autoimmun endocrinopathia ismerete sem elhanyagolható. Egyes kórképeket, például az autoimmun pajzsmirigybetegségeket a gyakoriságuk tesz kiemelten fontossá, más kórképek cukorbetegséggel együtt alakulnak ki, sokszor valamely polyglandularis autoimmun szindróma formájában. Irásunkban összefoglaljuk az egyes autoimmun endokrin kórképek és a polyglandularis endocrinopathiák legfontosabb jellemzöit, különös tekintettel azok diabetológiai vonatkozásaira.

Kulcsszavak: endokrin betegségek, autoimmunitás, diabetes mellitus
\end{abstract}

\section{Autoimmune endocrinopathies and diabetes}

Summary: Nearly all types of endocrine disfunctions affect glucose homeastasis posing both diagnostic and therapeutic challenges for clinicians. The under-and overactivity of endocrine glands is frequently the result of some underlying autoimmunity. Though amongst these conditions type 1 diabetes is of preeminent importance for the practicing diabetologist, familiarization with the other autoimmune endocrinopathies is also of key importance. For certain conditions, like autoimmune thyroid diseases, their significance is derived from their commonality. For others, it is their frequent co-occurrence with diabetes in the form of a polyglandular autoimmune syndrome. In this present paper we outline the most important features of autoimmune endocrinopathies with special focus on their relationship to diabetes.

Keywords: endocrine diseases, autoimmunity, diabetes mellitus

\section{Rövidítések}

AITD: autoimmun pajzsmirigybetegségek (autoimmune thyroid disorders); anti-TPO: thyreoidea-peroxidáz elleni autoantitestek (anti-thyroid peroxidase antibodies); CTLA: citotoxikus T-limfocita-asszociált antigén; HIV: emberi immunhiány-előidéző vírus (human immunodeficiency virus); IAS: inzulin autoimmun szindróma (insulin autoimmune syndrome); IGF-1: inzulinszerü növekedési faktor-1 (insulin-like growth factor 1); IRAb: inzulinreceptor-ellenes autoantitestek (anti-insulin receptor antibody); MHC: fö hisztokompatibilitási komplex (major histocompatibility complex); PAS: polyglandularis autoimmun szindróma (polyglandular autoimmune syndrome); SLE: szisztémás lupus erythematosus (systemic lupus erythematosus); TBIRS: B-típusú inulinrezisztencia-szindróma (type B insulin resistance syndrome)

\section{Pajzsmirigybetegségek}

Az autoimmun pajzsmirigybetegségek (AITD) adják a diabetes után az endokrin kórképek második leggyakoribb csoportját. Összesített prevalenciájuk
5-10\% között van, ami önmagában is jelentős, ám előfordulásuk a cukorbetegek körében ennél is gyakoribb. 2-es típusú cukorbetegekben (T2DM) az AITD-k 12-16\%-os prevalenciájáról számolnak be. ${ }^{1} \mathrm{Az}$ összefüggés az 1-es típusú diabetes 
(T1DM) esetében még erősebb. Egyes vizsgálatokban $30 \%$ feletti prevalenciát is leírtak, míg az anti-TPO-pozitivitás 1-es típusú cukorbetegek körében $40 \%$ körüli. GADA-pozitív cukorbetegekben a pajzsmirigybetegség rizikója 3-5-szörös. ${ }^{2}$ A T1DM és AITD együttesét ma mint a polyglandularis autoimmun szindróma III-as típusát tartjuk számon. Ennek hátterében több genetikai locust (HLA, CTLA-4, PTPN22, FOXP3) az elmúlt évtizedekben azonosítottak. ${ }^{3}$

Basedow-kórban a pajzsmirigyszövet elleni autoimmun reakció TSH-receptor elleni serkentő antitestek (TRAb) képződéséhez és következményes hyperthyreosishoz vezet. Pajzsmirigy-túlműködésben az endogén és exogén inzulin felezési ideje csökken, a szénhidrátfelszívódás hatásfoka a bélből megnő, a lipolízis és a glükoneogenezis fokozódik. Mindez a vércukorszint megemelkedésével, cukorbetegekben csökkenő glikémiás kontrollal jár., Kezeletlen hyperthyreosis mellett a ketoacidosis kockázata is jelentősen megnő.

A hypothyreosis messze leggyakoribb oka minden korcsoportban a krónikus lymphocytás vagy Hashimoto-thyreoiditis. A pajzsmirigy elleni autoimmun reakció ebben a kórképben a mirigyállomány fokozatos pusztulásán keresztül vezet alulműködéshez. A betegséget típusos módon thyreoidea-peroxidáz elleni autoantitestek (anti-TPO) jelenléte kíséri. Részben hasonló autoimmun mechanizmus feltételezett a postpartum thyreoiditis hátterében, amely a szülést követő egy évben a nők 8-10\%-át érinti. A Hashimoto-thyreoiditisszel szemben ez a kórkép csak ritkán, az esetek kevesebb mint 5\%-ában vezet tartós hypothyreosishoz. A manifeszt hypothyreosist csökkent glükoneogenezis jellemzi, ami T1DM egyidejü fennállása esetén az inzulinigény csökkenésével jár. ${ }^{5}$ Ilyen esetekben a pajzsmirigybetegség fennállását a hypoglykaemiás epizódok gyakoribbá válása korán jelezheti.

A perifériás szövetek inzulin mediálta glukózfelhasználásának csökkenését hypothyreosisban számos vizsgálat igazolta. 2-es típusú diabetes és hypothyreosis egyidejű fennállása esetén a pajzsmirigy alulműködésének ez az inzulinrezisztenciát fokozó hatása kerül előtérbe. ${ }^{6}$ A metabolikus szindróma gyakorisága már szubklinikus hypothyreosisban emelkedik. Ennek az összefüggésnek a fordítottja is ismert. A szubklinikus és manifeszt hypothyreosis prevalenciája nagyobb a metabolikus szindrómában szenvedők körében. 2-es típusú cukorbetegekben az emelkedett TSH a retinopathia és nephropathia kockázatát és súlyosságát fokoz$\mathrm{za}^{7,8} \mathrm{Ez}$ az összefüggés a hypothyreosis kezelésével reverzibilisnek tűnik.

A pajzsmirigybetegségek szénhidrát-anyagcserére gyakorolt hatását tovább komplikálja a pajzsmirigyfunkció kiszámíthatatlan ingadozása ezekben a kórképekben. Basedow-kórban a hyperthyreosis mértéke stabil kezelés mellett is drámai változásokat mutathat. A Hashimoto-thyreoiditis kezdetben néha mint thyreotoxicosis manifesztálódik.

A fentiek alapján megfogalmazható, hogy diabeteses betegekben a pajzsmirigybetegség legkisebb gyanúja esetén is indokolt a TSH-mérés. Rutinszerű szűrésre vonatkozó ajánlást az irányelvek egyelőre nem tartalmaznak. Cukorbetegség és pajzsmirigybetegség egyidejű fennállása esetén mindkét kórkép szoros kontrollja szükséges. Hyperthyreosis esetén lehetőség szerint a gyógyszeres kezelés helyett mielőbbi definitív megoldás (jódizotóp-kezelés vagy műtét) javasolható.

\section{Addison-kór}

A hypadreniás esetek 70-90\%-ának hátterében a mellékvesekéreg mindhárom rétegének autoimmun gyulladás okozta krónikus pusztulása, autoimmun adrenalitis áll. A kórkép ritka, prevalenciája 1,5/10000 körüli. A betegséget irreverzibilis, progresszív lefolyás és a szteroidszintézist végző enzimek, leggyakrabban a 21-hidroxiláz elleni autoantitestek jelenléte jellemzi. ${ }^{9}$ Az esetek több mint felében a hypadreniát egyéb autoimmun kórkép kíséri, amely mintegy 10\%-ban T1DM. Ezt az együttállást mint 2 -es típusú polyglandularis autoimmun szindróma vagy Schmidt-szindróma ismerjük. ${ }^{10}$ Hypadrenia és T1DM együttesével járhat emellett a polyglandularis autoimmun szindróma juvenilis vagy 1 -es típusa is (ld. lentebb). A másik oldalról vizsgálva a dolgot, autoimmun hypadrenia az 1-es típusú cukorbetegek kevesebb mint 1\%-ában alakul ki. ${ }^{11} \mathrm{~A}$ diabetes kialakulása rendszerint megelőzi a mellékvese-elégtelenséget. Ritkasága ellenére, tekintettel a potenciálisan halálos lefolyásra, az egyszerű diagnosztikára és olcsó kezelésre, több szerző is az 1-es típusú diabeteses betegek hypadrenia irányú rutinszerű szűrése mellett 
foglal állást. Ez a vélemény ugyanakkor ajánlás szintjén aktuálisan nem jelenik meg.

A kontrainzuláris hormonok csökkenő szintje a hypadrenia kezdetekor csökkent inzulinigényként, visszatérő hypoglykaemiák formájában, sokszor minden más tünet előtt jelentkezhet diabeteses betegekben. Bár a visszatérő hypoglykaemiáknak messze nem a hypadrenia a leggyakoribb oka, a fentiekre tekintettel klinikai gyanú esetén javasolt rövid ACTH-teszt végzése.

Hypadreniában az optimálisan beállított glükokortikoidpótlás sem tekinthető teljesen fiziológiásnak. Ez a különbség a Schmidt-szindrómás betegek glikémiás kontrolljában a hétköznapokban kevéssé mutatkozik meg. A perioperatív ellátás, illetve egyéb stesszhelyzetekben megnövelt szteroidpótlás mellett azonban számolnunk kell a szénhidrátháztartás felborulásával.

\section{Autoimmun hypoglykaemia-szindrómák}

Az autoimmun eredetű hypoglykaemiák az endogén hyperinsulinaemiás hypoglykaemiák közé tartoznak. Előfordulásuk az európai népesség körében extrém ritka, nem meglepő tehát, hogy a diagnózis ezekben a betegekben sokszor késik. Az inzulin autoimmun szindróma (IAS) vagy Hirata-betegség első leírása óta közel 50 év telt el. Az ebben az időszakban publikált nagyjából 500 eset nagy része Japánból származik, ahol az insulinoma és egyéb malignitások után ez a betegség a hypoglykaemia harmadik vezető oka. ${ }^{12}$ A kórkép jellemzően 40 év felett jelentkezik, mindkét nemet egyformán érinti. Hátterében több hajlamosító MHC II (major hisztokompatibilitási komplex) variánst azonosítottak. Gyakran előzi meg vírusfertőzés, illetve sok esetben valamely hematológiai malignitáshoz, illetve egyes gyógyszerek szedéséhez társul. Utóbbiak közül elterjedt használatuk miatt kiemelhetők a thyreostaticumok, a tioktánsav, illetve a clopidogrel. A betegséget inzulinellenes autoantitestek nagy titere jellemzi, amelyek az endogén inzulin megkötésével rezervet képeznek, lassítva ezzel az inzulin clearancét. ${ }^{13}$ Az igen változó súlyosságú éhomi vagy postprandialis hypoglykaemiás rosszullétek jellemzően a megkötött inzulin antitestekről történő disszociációját követik. A betegséget típusosan emelkedett széruminzulinszint és közel normális C-peptid-koncentráció jellemzi. A diagnózis alapját az antitestek kimutatása és az esetleges pancreas-patológia kizárása jelenti. Az elmúlt években több szerző beszámolt inzulinellenes antitestek jelenlétéről inzulinalógokkal kezelt T1DM-betegekben is. Felmerül ezen antitestek és az általuk okozott „szekunder IAS” oki szerepe a nehezen beállítható, labilis glikémiás kontrollal bíró cukorbetegség egyes eseteiben. ${ }^{14,15}$

A B-típusú inulinrezisztencia-szindróma (TBIRS) a legtöbb súlyos, jellemzően veleszületett inzulinrezisztencia-formával szemben szerzett autoimmun betegség. Hátterében inzulinreceptor-ellenes autoantitestek (IRAb) állnak. 1976-os első leírása óta csak mintegy 70 esetet diagnosztizáltak. A kórkép gyakran társul egyéb autoimmun kórképekhez (leggyakrabban SLE-hez), szolid tumorokhoz, hematológiai malignitásokhoz és ritkán antivirális kezeléshez. ${ }^{16}$ A TBIRS-t nehezen kontrollálható diabetes, valamint az inzulinrezisztencia egyéb klasszikus tünetei, mint acanthosis nigricans, nőkben polycystás ovariumok és hyperandrogenismus jellemzi. Az autoantitestek gátló és ezáltal inzulinrezisztenciát eredményező hatását egy rövidebb inzulin-mimetikus serkentő fázis előzi meg. Ezt a bifázisos hatásmechanizmust tételezik fel a viszszatérő hypoglykaema hátterében, amely ritkán a diabeteses tüneteket megelőzheti, illetve az esetek mintegy $10 \%$-ában a betegség egyetlen manifesztációja lehet. ${ }^{17}$ A kórkép diagnózisa a fentebb vázolt klinikai kép ismeretén alapul. IRAb-kimutatás a klinikai gyakorlatban jelenleg nem érhető el. Bár néhány esetben az autoantitestek spontán titercsökkenését is leírták, a betegek nagy része kombinált immunszupresszióra szorul. Az euglykaemia eléréséhez emellett igen jelentős, egyes esetekben több 10000 E-s inzulinigényről is beszámoltak. Szerepe lehet a terápiában emellett a metforminnak, a tiazolidindionoknak, a DPP-4-gátlóknak, a GLP-1analógoknak és az IGF-1-nek is.

\section{Polyglandularis autoimmun szindrómák}

A különböző endokrin diszfunkciók gyakori halmozódását először 1908-ban írták le. A polyglandularis autoimmun szindrómáknak (PAS), patogenetikai hátterük feltérképezésével, ezt követően számos felosztása született. ${ }^{18}$ Aktuálisan 
megkülönböztetünk monogénes/juvenilis/I-es, illetve poligénes/multifaktoriális/felnőttkori PASformákat. Utóbbiakat az érintett szervek együttese alapján II-IV-ig osztályozzuk.

A juvenilis PAS vagy APECED szindróma (autoimmune polyendocrinopathia, candidiasis és ectodermalis dystrophia) ritka megbetegedés, incidenciája 1:100000 körül van. Hátterében a 21es kromoszóma hosszú karján található AIRE gén több mint 60 különböző defektusát azonosították. ${ }^{19}$ A gén által kódolt fehérje a thymus epitheliumában az immuntolerancia kialakításában vesz részt, elégtelensége érthető módon az autoimmunitás irányába mozdítja az immunrendszert. A tünetek többnyire az 5. életév előtt kezdődnek, jellemzően kiterjedt candidiasissal, amit a későbbiekben hypoparathyreosis, hypocalcaemia és tetania, majd hypadrenia követ. Az esetek kevesebb mint harmadában a fentiekhez T1DM, hypogonadismus és/vagy autoimmun pajzsmirigybetegség is társul. Extraglandularis manifesztációként a candidiasison kívül gyakran jelentkeznek további autoimmun bőrtünetek; alopecia (16-40\%) és vitiligo (8-25\%), illetve autoimmun hepatitis és atrophiás gastritis is. A teljes klinikai kép jellemzően 15 éves kor előtt kifejlődik. A diagnózist a tünetek felismerése mellett a hozzátartozók érintettsége, illetve a napjainkban már elérhető genetikai vizsgálatok segítik. Az autoantitestek közül legnagyobb szenzitivitása az interferon- $\omega$ és $-\alpha$ antitesteknek van, amelyek mellett számos egyéb szervspecifikus autoantitest ismert. A terápiában az egyes endokrin diszfunkciók adekvát kezelésén túl jelentős szerep jut a kombinált immunszupresszív terápiának is.

A felnőttkori PAS-formák prevalenciája 1:20000 körüli, az inkomplett-szubklinikus formáké hozzávetőleg egy nagyságrenddel nagyobb. Az öröklődés poligénes domináns, a genetikai háttér a PAS-I-nél jóval heterogénebb, és a környezeti tényezők szerepe is jóval nagyobbnak tűnik. A betegség egypetéjü ikrekben sem alakul ki 100\%-os konkordanciával. Az ez idáig azonosított klinikailag szignifikáns genetikai locusok nagy része az MHC I és II osztályba tartozik. Szemben a PAS-I-gyel, amelyben a két nem nagyjából egyformán érintett, a felnőttkori PAS-formákra jelentős (75\%) női túlsúly jellemző. A klinikai kép igen változatos. Szemben a juvenilis PAS-sal, ahol az egyes szervi manifesztációk jellemzően gyors egymásutánban jelentkeznek, a felnőttkori esetekben jellemzően évtizedek telnek el az egyes endocrinopathiák kialakulása között, amelyek közül sokszor a T1DM az első. ${ }^{20}$

Ahogy korábban is említettük, a PAS II vagy Schmidt-szindróma az Addison-kór és egyéb endocrinopathiák társulását jelenti. Ez a forma a második leggyakrabban előforduló felnőttkori PAS-típus. Gyakoriságban vezető helyen az esetek körülbelül 40\%-át adó, már szintén említett III-as típus áll, amely a T1DM és az autoimmun pajzsmirigybetegségek társulását jelenti. Bár minden polyglandularis autoimmun szindrómában előfordulnak, a III-as típusú PAS-ban a leggyakoribbak a társuló extraglandularis autoimmun betegségek, mint atrophiás gastritis, anemia perniciosa, atopiás ekcéma, alopecia areata, myasthenia gravis, SLE, rheumatoid arthritis és autoimmun hepatitis. Nem endokrin autoimmun szervi érintettség a felnőttkori PAS-esetek 40-50\%-ában alakul ki. A PAS IVes típusába, amely az esetek elenyésző hányadát adja, a T1DM és egyéb ritkább endocrinopathiák: primer hypogonadismus, hypoparathyreosis, autoimmun hypopituitarismus együttesét soroljuk. A juvenilis és a felnőttkori polyglandularis autoimmun formákra jellemző endokrin szervi

1. táblázat. A juvenilis és a felnőttkori polyglandularis autoimmun formák endokrin szervi manifesztációi és azok relatív gyakorisága

\begin{tabular}{|c|c|}
\hline Juvenilis PAS (I-es típus) & Felnöttkori PAS (II-IV-es típus) \\
\hline Hypoparathyreosis (80-85\%) & Autoimmun pajzsmirigybetegség (70-75\%) \\
\hline Addison-kór (60-70\%) & T1DM (40-60\%) \\
\hline T1DM (2-33\%) & Addison-kór (40-50\%) \\
\hline Hypogonadismus (12\%) & Hypoparathyreosis ( $\leq 5 \%)$ \\
\hline Autoimmun pajzsmirigybetegség (10\%) & Hypoponadismus ( $\leq 3 \%)$ \\
\hline Mucocutan candidiasis (70-80\%) & \\
\hline
\end{tabular}


manifesztációkat és azok relatív gyakoriságát az 1. táblázat foglalja össze. ${ }^{21}$

\section{latrogén autoimmun endokrin diszfunkciók}

A biológiai terápiák korában egyre több gyógyszerrel kapcsolatban igazolódik, hogy mellékhatásként autoimmun endocrinopathiát okoz. A hepatitis $C$ vírusos fertőzés kezelésében korábban első vonalban alkalmazott interferon-alfa-terápia a betegek 5-10\%-ában vezetett autoimmun pajzsmirigybetegséghez (Basedow-kór és Hashimoto-thyreoiditis), illetve ritkábban 1-es típusú cukorbetegséghez. ${ }^{22} \mathrm{Az}$ előrehaladott vesetumorok és a melanoma immunterápiájára törzskönyvezett IL-2 (aldesleukin) használata mellett 16\%-ban jelentkezik Hashimoto-thyreoiditis. ${ }^{23} \mathrm{Az}$ aldesleukinhez hasonló indikációs körben alkalmazott CTLA-4-gátló ipilimumab adása mellett a betegek több mint felénél jelentkezett valamely endokrin diszfunkció vagy nem endokrin autoimmun kórkép. ${ }^{24} \mathrm{~A}$ hematológiai indikációk mellett napjainkban a sclerosis multiplex kezelésében is bevezetett CD52-gátló alemtuzumab, különösen nagyobb dózisok használata mellett, 30\%-ban okoz autoimmun pajzsmirigybetegséget, amely akár 2 évvel a kezelés befejezése után is manifesztálódhat. ${ }^{25}$ A HIV-kezelésben alkalmazott nagy hatékonyságú antiretrovirális kezelés (highly active antiretroviral therapy - HAART) kombinációk mellett ritkán Basedow-kór, még ritkábban egyéb endokrin betegségek megjelenését írták le. ${ }^{26}$

\section{Föbb megállapítások}

Összefoglalásként elmondhatjuk, hogy a diabeteshez társuló endocrinopathiák a cukorbetegek szénhidrátanyagcseréjét, aktivitását, compliance-ét és a diabetes hosszú távú szövődményeit egyaránt befolyásolják. Az 1-es típusú diabetes a PAS szindrómák egyik leggyakoribb alkotóeleme. Az esetek mintegy 50-60\%-ában van jelen, és gyakran akár évtizedekig a betegség egyetlen tünete lehet. A további endokrin és extraglandularis manifesztációk korai felismerésében, ezáltal az adekvát kezelés megkezdésében és az esetleges súlyos szövődmények elkerülésében jelentős szerep hárul a gondozó diabetológusokra.
Irodalom

1. Perros P, McCrimmon RJ, Shaw G, Frier BM: Frequency of thyroid dysfunction in diabetic patients: value of annual screening. Diabet Med 1995; 12(7): 622-627. doi:10.1111/j.1464-5491.1995.tb00553.x

2. Kordonouri 0 , Charpentier $N$, Hartmann R: GADA positivity at onset of type 1 diabetes is a risk factor for the development of autoimmune thyroiditis. Pediatr Diabetes 2011; 12(1):31-33. doi:10.1111/j.1399-5448.2010.00666.x

3. Villano MJ, Huber AK, Greenberg DA, Golden BK, Concepcion E, Tomer $Y$ : Autoimmune thyroiditis and diabetes: dissecting the joint genetic susceptibility in a large cohort of multiplex families. I Clin Endocrinol Metab 2009; 94(4): 1458-1466. doi:10.1210/jc.2008-2193

4. Maxon HR, Kreines KW, Goldsmith RE, Knowles HC Jr: Long-term observations of glucose tolerance in thyrotoxic patients. Arch Intern Med 1975; 135(11): 1477-1480. D01:10.1001/archinte.1975.00330110067 009

5. Leong KS, Wallymahmed M, Wilding J, MacFarlane I: Clinical presentation of thyroid dysfunction and Addison's disease in young adults with type 1 diabetes. Postgrad Med J 1999; 75(886): 467-470. doi:10.1136/pgmj.75.886.467

6. Maratou E, Hadjidakis DJ, Kollias A, Tsegka K, Peppa M, Alevizaki $M$, et al: Studies of insulin resistance in patients with clinical and subclinical hypothyroidism. Eur I Endocrinol 2009; 160(5): 785-790. doi:10.1530/EJE-08-0797

7. Chen HS, Wu TE, Jap TS, Lu RA, Wang ML, Chen RL, et al: Subclinical hypothyroidism is a risk factor for nephropathy and cardiovascular diseases in Type 2 diabetic patients. Diabet Med 2007; 24(12): 1336-1344. doi:10.1111/j.1464-5491.2007.02270.x

8. Yang GR, Yang JK, Zhang L, An YH, Lu JK: Association between subclinical hypothyroidism and proliferative diabetic retinopathy in type 2 diabetic patients: a case-control study. Tohoku J Exp Med 2010; 222(4): 303-310. doi:10.1620/tjem.222.303

9. Erichsen $M M 1$, Løvås $K$, Skinningsrud $B$, Wolff $A B$, Undlien $D E$, Svartberg J, et al: Clinical, immunological, and genetic features of autoimmune primary adrenal insufficiency: observations from a Norwegian registry. I Clin Endocrinol Metab 2009; 94(12): 4882-4890. doi:10.1210/jc.2009-1368

10. Neufeld M, Maclaren NK, Blizzard RM: Two types of autoimmune Addison's disease associated with different polyglandular autoimmune (PGA) syndromes. Medicine (Baltimore). 1981; 60(5): 355-362. doi:10.1097/00005792-198109000-00003

11. Barker JM, Ide A, Hostetler C, Yu L, Miao D, Fain PR, et al:: Endocrine and immunogenetic testing in individuals with type 1 diabetes and 21-hydroxylase autoantibodies: Addison's disease in a high-risk population. J Clin Endocrinol Metab 2005; 90(1): 128-134. doi:10.1210/jc.2004-0874

12. Uchigata $Y$, Hirata $Y$, Iwamoto $Y$ : Drug-induced insulin autoimmune syndrome. Diabetes Res Clin Pract 2009 83(1): e19-20. doi:10.1016/j.diabres.2008.10.015

13. Ismail AA: The insulin autoimmune syndrome (IAS) as a cause of hypoglycaemia: an update on the pathophysiology, biochemical investigations and diagnosis. Clin Chem Lab Med 2016; 54(11): 1715-1724. doi: $10.1515 / \mathrm{cclm}-2015-1255$

14. Lamy PJ, Sault C, Renard E: High fasting serum insulin level due to autoantibody interference in insulin immunoassay discloses autoimmune insulin syndrome: a case report. Ann Biol Clin (Paris) 2016; 74(4): 490-494. doi:10.1684/abc.2016.1168

15. Sharwood EF, Hughes IP, Pretorius (J, Trnka P, Peake J, Huynh T: Therapeutic plasma exchange normalizes insulin-mediated response in a child with type 1 diabetes and insulin autoimmune syndrome. Pediatr Diabetes 2018; 19(1): 171-179. doi:10.1111/pedi.12522 
16. Arioglu E, Andewelt A, Diabo C, Bell M, Taylor SI, Gorden P: Clinical course of the syndrome of autoantibodies to the insulin receptor (type B insulin resistance): a 28-year perspective. Medicine (Baltimore) 2002; 81(2): 87-100. doi:10.1097/00005792-200203000-00001

17. Censi S, Mian C, Betterle C: Insulin autoimmune syndrome: from diagnosis to clinical management. Ann Transl Med 2018; 6(17): 335. doi:10.21037/atm.2018.07.32

18. Kahaly GJ: Polyglandular autoimmune syndromes. Eur J Endocrinol Eur Fed Endocr Soc 2009; 161(1): 11-20. doi:10.1530/EJE-09-0044

19. Cutolo M: Autoimmune polyendocrine syndromes. Autoimmun Rev 2014, 13(2): 85-89. doi:10.1016/j.autrev.2013.07.006

20. Hansen MP, Matheis N, Kahaly GJ: Type 1 diabetes and polyglandular autoimmune syndrome: a review. World J Diabetes 2015; 6(1): 67-79. doi:10.4239/wjd.v6.i1.67

21. Kahaly GJ, Frommer L: Polyglandular autoimmune syndromes. J Endocrinol Invest 2018; 41(1): 91-98. doi:10.1007/s40618-017-0740-9

22. Russo MW, Fried MW: Side effects of therapy for chronic hepatitis C. Gastroenterology 2003; 124(6): 1711-1719. doi:10.1016/s0016-5085(03)00394-9

23. Weijl NI, Van der Harst D, Brand A, Kooy Y, Van Luxemburg S, Schroder J, et al.: Hypothyroidism during immunotherapy with interleukin-2 is associated with antithyroid antibodies and response to treatment. I Clin Oncol 1993; 11: 1376-1383. doi:10.1200/JC0.1993.11.7.1376
24. Savoia P, Astrua C, Fava P: Ipilimumab (Anti-Ctla-4 Mab) in the treatment of metastatic melanoma: Effectiveness and toxicity management. Hum Vaccin Immunother 2016; 12(5): 1092-101. doi:10.1080/21645515.2015.1129478

25. Jones $\mathrm{L}$, Coles AJ: Campath-1H treatment of multiple sclerosis. Neurodegener Dis 2008; 5: 27-31. doi:10.1159/000109935

26. Chen F, Day SL, Metcalfe RA, Sethi G, Kapembwa MS, Brook MG, et al.: Characteristics of autoimmune thyroid disease occurring as a late complication of immune reconstitution in patients with advanced human immunodeficiency virus (HIV) disease. Medicine (Baltimore) 2005; 84(2): 98-106. doi:10.1097/01.md.0000159082.45703.90

Közlésre érkezett: 2019. március 21.

Közlésre elfogadva: 2019. október 8.

\section{A levelezésért felelös szerzö címe:}

\section{Dr. Takács István}

Semmelweis Egyetem, I. Belgyógyászati Klinika 1083 Budapest, Korányi Sándor utca 2/a

E-mail: takacs.istvan@med.semmelweis-univ.hu 